\title{
FRUIT SET OF SEVERAL SOUR CHERRY CULTIVARS IN LATVIA INFLUENCED BY WEATHER CONDITIONS BEFORE AND DURING FLOWERING
}

\author{
Daina Feldmane ${ }^{1}$, Silvija Ruisa ${ }^{1}$, Valentīna Pole ${ }^{1}$, Madalina Butac ${ }^{2}$, \\ and Madalina Militaru ${ }^{2}$ \\ ${ }^{1}$ Institute of Horticulture, Latvia University of Agriculture, Graudu iela 1, Cerini, Krimūnu pag., Dobeles nov., LV-3701, LATVIA; \\ daina.feldmane@llu.lv \\ ${ }^{2}$ Research Institute for Fruit Growing Pitesti, OP1, CP73, 110006, Arges, ROMANIA
}

Communicated by Edite Kaufmane

\begin{abstract}
Fruit set is a crucial stage in the process of yield formation, which is influenced by environmental factors, growing technologies and peculiarities of genotype. The aim of the study was to evaluate the quality of pollen (viability and germination capacity) and the effect of weather before and during flowering on fruit set in sour cherry cultivars 'Latvijas Zemais', 'Zentenes', 'Bulatnikovskaya', and 'Orlica'. The research was carried out in Institute of Horticulture (Latvia University of Agriculture) in 2009-2016. Good pollen viability and germination was found for cultivars 'Latvijas Zemais' and 'Bulatnikovskaya'. Negative effects of increasing air temperature (in the range of 7.7 to $17.5^{\circ} \mathrm{C}$ ) and relative humidity (in the range of 51.4 to $88.5 \%$ ) was observed for all cultivars during flowering. The effects of diurnal temperature fluctuations, wind and the amount of days with precipitation differed depending on sour cherry cultivar.
\end{abstract}

Key words: Prunus cerasus, pollen, air temperature, relative humidity.

\section{INTRODUCTION}

Fruit set (FS) is a crucial stage in the process of yield formation, which is influenced by environmental factors, growing technologies and genotype. Air temperature is one of most important factors, which is closely related to other meteorological conditions like relative humidity, wind, sunshine etc.

Aside from the effect of accumulation of chill units and growing day degrees or heat units, temperature plays multiple role in processes of flower development before flowering. Studies conducted in Skopje, Macedonia showed the impact of temperature and drought on sour cherry microsporogenesis, which took place about 30 days before flowering (Popovska et al., 2005). Temperature fluctuation and drought during this time was related to irregularity in pollen mother cell division and therefore to disturbance of sour cherry pollen development. Diurnal temperature fluctuations of sunny, warm days and cool nights before flowering advanced the beginning of flowering and shortened its duration (Nyéki et al., 2014). Warm pre-blossom temperatures caused earlier flowering but underdeveloped pistils and decreased FS set in apricots (Rodrigo and Herrero, 2002). A study of sweet cherry flowers showed the role of temperature in the growth of style and filament (Zhang et al., 2015).
After the stage "tight cluster", flowers developing in low temperature had shorter styles and filaments, compared to those developing at higher temperature. In Denmark, low FS of sour cherries was observed after prolonged periods with high humidity and low temperatures during flower development from bud burst to first white (Hansted et al., 2012).

During flowering, temperature and other weather conditions influence partially overlapping events: pollen distribution and pollination (including insect activity) as well as fructification related to stigmatic receptivity, pollen germination, ovule longevity and pollen tube penetration in the locule of the ovary.

Warm weather is favourable for pollen carrying insects, especially for honeybee activity. Honeybee colonies in plantations increased sour cherry FS significantly (Hansted et al., 2012). However, here effect of genotype is also important - fruit set of self-fertile cultivars is less dependent on insect activity than of self-sterile or partially self-fertile cultivars.

Optimal temperatures have been found for pollen tube growth in sour cherries in Serbia (Cerovič and Ružič, 1992; Cerovič et al., 1997) and in sweet cherries in Poland (Lech 
et al., 2012), where pollen tube growth was advanced by higher temperature in a certain range.

In contrast, faster senescence of sour cherry ovules (Postweiler et al., 1990; Cerovič and Družič, 2010) and decreasing stigma receptivity in sweet cherries (Hedhly et al., 2003) was detected in conditions of increasing temperature. E. Szpadzik reported delayed appearance of stigma secretion at temperatures below $6{ }^{\circ} \mathrm{C}$ (Szpadzik et al., 2014).

Several effects of wind and air relative humidity on fruit set were found. Negative impact of strong wind on pollinatorinsect activity was observed (Vicens and Bosch, 2000). Relative humidity significantly influenced pollen tube growth in the upper part of stigma in sweet cherries (Lech et al., 2012). Disturbed release of pollen from anthers in conditions of high humidity, but decreased germination of pollen in low humidity may occur. Wind can affect sour cherry 'Stevnsbaer' pollen distribution and a negative correlation can occur between the amount of airborne pollen and humidity but positive with temperature (Hansted et al, 2012).

Significant variability among sour cherry cultivars regarding fruit set and its optimum conditions have been described in many studies, but little is known about cultivars grown in the Baltic countries. 'Latvijas Zemais' is the most widely grown sour cherry cultivar in Latvia for a long time. The general relatedness of 'Latvijas Zemais' to Scandinavian sour cherry cultivars and genetic distinction from other cultivars has been described (Lācis et al., 2011; Lācis and Kota, 2013), but there still is lack of more detailed research about its origin. There is no information yet about the origin and genetic relatedness of landrace 'Zentenes', which has been recommended for growing recently. The cultivars ' $\mathrm{O}$ rlica' and 'Bulatnikovskaya' were introduced from Russia, where they have been recommended for growing in the central part of state. According to the information given in the official web-site of VNIISPK Institute (http://vniispk.ru), 'Bulatnikovskaya' is a seedling of freely pollinated 'Shirpotreb Chornaya' $(P$. cerasus 'Yubileinaya' $\times P$. avium 'Pervenec'), and 'Orlica' is a seedling of 'Zhukovskaya' in free pollination. Fruit set of $17.6 \%$ was observed for 'Shirpotreb Chornaya' and of $23.5 \%$ for 'Zhukovskaya' in Germany (Schuster and Wolfram, 2004).

The aim of the study was to evaluate the properties of pollen (viability and germination capacity) and the effect of weather before and during flowering on fruit set of sour cherry cultivars 'Latvijas Zemais', 'Zentenes', 'Bulatnikovskaya', and 'Orlica'.

\section{MATERIALS AND METHODS}

The research was carried out in the Institute of Horticulture (Latvia University of Agriculture) in 2009-2016 on the basis of an existing two-factorial trial for investigation of the effect of drip irrigation and woodchip mulch vs. control on various sour cherry cultivars planted in spring 2007. Soil characteristics in the planting year were: slightly acid clayic
Podzoluvisol soil ( $\mathrm{pH}$ 6.4); the content of plant available phosphorus and potassium was $122 \mathrm{mg} \cdot \mathrm{kg}^{-1} \mathrm{P}_{2} \mathrm{O}_{5}$ and 149 $\mathrm{mg} \cdot \mathrm{kg}^{-1} \mathrm{~K}_{2} \mathrm{O}$. Fertilisation was done accordingly to results of soil analysis. Weeds, pests, and diseases were controlled according to integrated plant protection management. Perennial grasses were sown between tree strips and mown several times during vegetation seasons.

Fruit set was studied for cultivars 'Latvijas Zemais', 'Zentenes', 'Bulatnikovskaya', and 'Orlica' (rootstock - seedlings of Prunus mahaleb L.) determining the ratio of fruit and flower number on sample shoots as a percentage. Flowers and fruits after free pollination were counted on typical shoots growing at height of $1.2-1.5 \mathrm{~m}$ on every tree in the trial (6 to 10 trees of each cultivar).

Meteorological data was collected in the station LUFFT located within the orchard. The following indices were used in further analysis:

- data collected during sour cherry flowering (from the beginning of flowering $\mathrm{BBCH} 61$ until the end of full flowering $\mathrm{BBCH}$ 65) - minimal, average, and maximum air temperature, average amplitude of diurnal temperature, the number of days with precipitation, average air humidity, most frequent wind direction, and average wind speed;

- data collected during 30 days before flowering (approximate beginning of bud burst) - minimum, average, and maximum air temperature, and average amplitude of diurnal temperature.

In 2014, self-pollination and cross-pollination combinations were tested for 'Latvijas Zemais' and 'Zentenes', including 'Bulatnikovskaya' and 'Haritonovskaya' as pollinators. Pollination was conducted in bagged shoots in the field, two times daily during flowering. Pollen was collected shortly before pollination from the flower buds in "balloon" stage (BBCH 59).

In 2014, the effect of an artificially propagated bumblebee colony (Biobest) was tested for the cultivars 'Latvijas Zemais', 'Zentenes', and 'Bulatnikovskaya'. A bumblebee hive was placed in the studied orchard at the beginning of sour cherry flowering. Fruit set of cherries grown without mulch nor irrigation was compared with the FS of the same cultivars in similar age (planted in 2008) grown in a $150 \mathrm{~m}$ distant orchard with similar soil conditions. Before this experiment, in 2013, FS was compared in both orchards, and it did not differ significantly.

In 2014 and 2015, pollen viability and germination was determined for cultivars 'Latvijas Zemais', 'Zentenes' and 'Bulatnikovskaya'. Flower buttons in balloon stage BBCH 59 were collected from orchard, anthers were removed and dried at $22-24{ }^{\circ} \mathrm{C}$. After 24 hours, anthers have cracked and pollen had released. Pollen viability was determined by the method of staining with acetic carmine. Fertile pollen coloured in carmine red, but sterile pollen remained less coloured or coloured in pink. Germination capacity was tested 
METEOROLOGICAL CONDITIONS DURING SOUR CHERRY FLOWERING IN 2009-2016

\begin{tabular}{|c|c|c|c|c|c|c|c|c|c|c|}
\hline \multirow[b]{2}{*}{ Year } & \multicolumn{2}{|c|}{ Time of flowering } & \multicolumn{4}{|c|}{ Air temperature during flowering time, ${ }^{\circ} \mathrm{C}$} & \multirow{2}{*}{$\begin{array}{l}\text { Number of } \\
\text { days with } \\
\text { precipitation }\end{array}$} & \multirow{2}{*}{$\begin{array}{l}\text { Air relative } \\
\text { humidity, \% }\end{array}$} & \multicolumn{2}{|c|}{ Wind } \\
\hline & $\begin{array}{l}\text { beginning of } \\
\text { flowering } \\
\text { (BBCH 61) }\end{array}$ & $\begin{array}{l}\text { the end of full } \\
\text { flowering (of } \\
\text { BBCH 65) }\end{array}$ & minimal & average & maximal & $\begin{array}{c}\text { average } \\
\text { diurnal } \\
\text { amplitude } \\
\end{array}$ & & & $\begin{array}{c}\text { average } \\
\text { speed, } \\
\mathrm{m} \cdot \mathrm{s}^{-1}\end{array}$ & $\begin{array}{c}\text { most frequent } \\
\text { direction }\end{array}$ \\
\hline 2009 & 5 May & 9 May & 4.7 & 11.4 & 19.1 & 9.4 & 0 & 70.3 & 1.8 & South West \\
\hline 2010 & 13 May & 18 May & 10.8 & 17.5 & 26.8 & 11.0 & 3 & 88.5 & 1.2 & various \\
\hline 2011 & 11 May & 15 May & 4.4 & 12.8 & 25.0 & 13.3 & 5 & 76.2 & 2.4 & South West \\
\hline 2013 & 11 May & 16 May & 4.3 & 15.2 & 28.6 & 11.9 & 4 & 77.7 & 1.6 & various \\
\hline 2014 & 30 April & 10 May & -1.1 & 7.7 & 17.6 & 9.7 & 6 & 73.2 & 2.5 & West \\
\hline 2015 & 6 May & 13 May & 2.7 & 11.7 & 20.0 & 12.1 & 2 & 72.0 & 2.6 & South \\
\hline 2016 & 6 May & 11 May & 6.2 & 9.4 & 26.1 & 15.5 & 0 & 51.4 & 1.2 & various \\
\hline
\end{tabular}

in vitro, by cultivation on solid nutrient medium: $1.5 \mathrm{~g}$ agar $+15 \mathrm{~g}$ sucrose $+0.01 \mathrm{~g}$ boric acid $\left(\mathrm{H}_{3} \mathrm{BO}_{3}\right)$ in $100 \mathrm{ml}$ distilled water, incubation of 16 hours at temperature of $24{ }^{\circ} \mathrm{C}$ and relative humidity of $70-90 \%$. At least 100 pollen grains were observed and counted, and the germination rate was calculated. When the length of the pollen tube exceeded its diameter, the pollen was considered as germinated. The examination was made using an optical microscope Leica, with an objective $\times 10-$ for germination capacity, objective $\times 40$ for pollen viability. Germination capacity beyond $40 \%$ was considered as satisfying normal fructification.

Data were statistically processed using analysis of variance with Duncan's test for post-hoc analysis and Kendal's tau b correlation in SPSS software.

\section{RESULTS}

Weather conditions and their general effect on fruit set. In Latvia, sour cherries flower mostly in the first decade of May, but earlier or later flowering may occur due to variable weather conditions. Sour cherry flowering time and meteorological conditions are shown in the Table 1.

The lowest air temperature (AT) during flowering was observed in 2014 , reaching $-1.1^{\circ} \mathrm{C}$, when the period with AT under $0{ }^{\circ} \mathrm{C}$ was 1.75 hours long on May 3 , before onset of full flowering. This decrease of AT did not affect fruit set of any cultivar. Highest minimum AT was $10.8{ }^{\circ} \mathrm{C}$ in 2010 . In other years, minimum AT fluctuated from 2.7 to $6.2^{\circ} \mathrm{C}$. Maximum air temperatures varied from 17.6 to $28.6{ }^{\circ} \mathrm{C}$, and average AT from 7.7 to $17.5{ }^{\circ} \mathrm{C}$.

Air temperature during 30 days before flowering fluctuated from $-5.6{ }^{\circ} \mathrm{C}$ (minimum temperature in 2014) to 29.0 (maximum temperature in 2013) (Table 2). The average AT before flowering was rather stable, from 7.6 to $9.1{ }^{\circ} \mathrm{C}$, and average diurnal amplitude was from 9.5 to $13.4{ }^{\circ} \mathrm{C}$.

Fruit set of all cultivars decreased when average AT during flowering increased - the correlations were negative, medium strong and highly significant $(r=-0.29 \ldots-0.41$, $p<0.01$ ). The effect of other indices of temperature before and during flowering differed among cultivars.
Table 2

AIR TEMPERATURE DURING 30 DAYS BEFORE SOUR CHERRY FLOWERING IN 2009-2016

\begin{tabular}{c|c|c|c|c}
\hline \multirow{2}{*}{ Year } & \multicolumn{4}{|c}{ Air temperature during 30 days before sour cherry flowering } \\
& \multicolumn{4}{|c}{ time, ${ }^{\circ} \mathrm{C}$} \\
\cline { 2 - 5 } & minimum & average & maximum & $\begin{array}{c}\text { average diurnal } \\
\text { amplitude }\end{array}$ \\
\hline 2009 & -2.7 & 9.1 & 26.3 & 13.4 \\
2010 & -1.9 & 8.0 & 23.3 & 10.6 \\
2011 & -1.8 & 9.4 & 23.4 & 12.0 \\
2013 & -2.8 & 9.2 & 29.0 & 12.0 \\
2014 & -5.6 & 8.3 & 23.3 & 11.5 \\
2015 & -0.1 & 8.0 & 20.1 & 9.5 \\
2016 & -1.7 & 7.6 & 20.3 & 10.8 \\
\hline
\end{tabular}

Generally, several rainy days occurred during sour cherry flowering, but in years 2009 and 2016 no precipitation was observed in this time. Response to the number of days with precipitation differed depending on the cultivar.

In most years, air relative humidity $(\mathrm{RH})$ fluctuated from 70.3 to $77.7 \%$ which is typical in Latvia. High RH was observed in 2010, reaching $88.5 \%$, and was low in 2016 when RH was $51.4 \%$. Fruit set of all cultivars responded negatively to increased air relative humidity during flowering and there was significant negative correlation $(\mathrm{r}=-0.29 \ldots$ $-0.43, p<0.01)$.

Wind speed varied from 1.2 to $4.3 \mathrm{~m} \cdot \mathrm{s}^{-1}$. Wind from the southern and western direction dominated in flowering for the four observation years, but no clearly dominating direction was detected in other years. The influence of wind on fruit set was different depending on the cultivar.

Features of cultivars in relation to weather conditions. 'Latvijas Zemais'.

The average fruit set of 'Latvijas Zemais' in this experiment was $15.6 \%$, with medium range among other cultivars. The average viability and germination capacity of pollen was sufficient for 'Latvijas Zemais' - $77.0 \%$ and $52.9 \%$, respectively (Table 3). Self-pollination resulted in fruit set of $4 \%$. Cross-pollination improved FS significantly: $12 \%$ after 
Table 3

POLLEN VIABILITY AND GERMINATION CAPACITY OF SOUR CHERRY CULTIVARS IN 2014 AND 2015

\begin{tabular}{l|ccc|cccc}
\hline \multirow{2}{*}{ Cultivar } & \multicolumn{3}{|c|}{ Pollen viability (\%) } & \multicolumn{3}{c}{ Germination capacity (\%) } \\
\cline { 2 - 7 } & 2014 & 2015 & average & 2014 & 2015 & average \\
\hline Latvijas Zemais & $75.83 \mathrm{a}$ & $78.09 \mathrm{a}$ & $76.96 \mathrm{a}$ & $46.77 \mathrm{ab}$ & $58.97 \mathrm{a}$ & $52.87 \mathrm{a}$ \\
Zentenes & $83.33 \mathrm{~b}$ & $85.71 \mathrm{a}$ & $84.52 \mathrm{c}$ & - & $32.26 \mathrm{~b}$ & $32.26 \mathrm{~b}$ \\
Bulatnikovskaja & $75.01 \mathrm{a}$ & $75.33 \mathrm{a}$ & $75.17 \mathrm{a}$ & $62.50 \mathrm{a}$ & $52.27 \mathrm{a}$ & $57.39 \mathrm{a}$ \\
Haritonovskaja & $83.75 \mathrm{~b}$ & $52.06 \mathrm{~b}$ & $67.91 \mathrm{~b}$ & $31.48 \mathrm{~b}$ & $33.91 \mathrm{~b}$ & $32.70 \mathrm{~b}$
\end{tabular}

$\mathrm{a}, \mathrm{b}$ - the values in columns marked with the same letters did not differ significantly $(\mathrm{p}<0.05)$

pollination with 'Zentenes' and $10 \%$ after pollination with 'Haritonovskaya'. However, the establishment of the bumblebee colony did not increase FS of 'Latvijas Zemais'. A weak, inverse correlation of minimal air temperature during flowering time with FS was found $(p<0.05)$ (Table 4$)$. Increase of diurnal temperature amplitude before flowering and during flowering had positive effect on fruit set. No significant effect of maximum air temperature, wind speed or direction, on duration of flowering time on FS was detected.

'Zentenes'. Fruit set of 'Zentenes' was significantly lower comparing to other cultivars $-5.5 \%$ on average. Pollen viability (average $84.5 \%$ ) of 'Zentenes' was high. However, in 2014, the amount of pollen released from anthers was so small that it was not enough to test germination. In 2015, germination capacity was acceptable (32.3\%).

'Zentenes' showed no fruit set after self-pollination (0 fruits in every replication). In contrast, cross-pollination with
'Latvijas Zemais', 'Haritonovskaya', and 'Bulatnikovskaya' led to fruit set of 9,17 , and $8 \%$, respectively.

Obviously, this cultivar requires a pollen donor and favourable conditions for pollen distribution. The establishment of a bumblebee colony significantly improved FS of 'Zentenes'. Fruit set in the orchard with the bumblebee hive was 1.6 times higher than in the orchard without it, and the effect was statistically significant. Further analysis of meteorological conditions and fruit set was done excluding the data of year 2014 due to significant impact of presence of the bumblebee hive.

Fruit set of 'Zentenes' was significantly higher (10.7\%) in years without precipitation, but in years with precipitation the average FS was $3.8 \%$. Correlation between fruit set and the number of days with precipitation was negative and significant $(p<0.05)$.

FS of 'Zentenes' was not significantly affected by wind direction and speed, minimum, and maximum air temperature, and duration of flowering. A weak negative correlation between average air temperature before flowering and FS was detected $(p<0.05)$ (Table 5).

'Bulatnikovskaya'. The average fruit set of 'Bulatnikovskaya' was higher than of other cultivars (18.3\%), but without significant difference of that of 'Latvijas Zemais'. Average pollen viability was $75.2 \%$, germination capacity $57.4 \%$. FS was improved by presence of the bumblebee colony, leading to 1.4 times higher fruit-flower ratio. The data of this year was excluded from further analysis of meteorological factors also for 'Bulatnikovskaya'.

Table 4

RELATION OF FLOWERING INDICES TO FRUIT SET OF SOUR CHERRY CULTIVARS DURING 2009-2016

\begin{tabular}{l|c|c|c|c|c|c|c|c}
\hline \multirow{3}{*}{ Cultivar } & \multicolumn{8}{c}{ Kendall's tau b correlation coefficient fowering time indices with fruit set } \\
\cline { 2 - 10 } & $\begin{array}{c}\text { minimum air } \\
\text { temperature, } \\
{ }^{\circ} \mathrm{C}\end{array}$ & $\begin{array}{c}\text { average air } \\
\text { temperature, } \\
{ }^{\circ} \mathrm{C}\end{array}$ & $\begin{array}{c}\text { maximum air } \\
\text { temperature, } \\
{ }^{\circ} \mathrm{C}\end{array}$ & $\begin{array}{c}\text { average diurnal } \\
\text { amplitude, } \\
{ }^{\circ} \mathrm{C}\end{array}$ & $\begin{array}{c}\text { number of days } \\
\text { with } \\
\text { precipitation }\end{array}$ & $\begin{array}{c}\text { air relative } \\
\text { humidity, } \\
\%\end{array}$ & $\begin{array}{c}\text { wind speed, } \\
\mathrm{m} \cdot \mathrm{s}^{-1}\end{array}$ & $\begin{array}{c}\text { Duration of } \\
\text { flowering time, } \\
\text { number of days }\end{array}$ \\
\hline Latvijas Zemais & $-0.17^{*}$ & $-0.40^{* *}$ & -0.12 & $0.13^{*}$ & -0.02 & $-0.41^{* *}$ & 0.08 & -0.06 \\
Zentenes & -0.11 & $-0.29 * *$ & -0.07 & -0.07 & $-0.29 * *$ & $-0.29 * *$ & -0.01 & 0.07 \\
Orlica & -0.05 & $-0.41^{* *}$ & $-0.34 * *$ & 0.04 & -0.10 & $-0.43^{* *}$ & $0.21^{* *}$ & -0.10 \\
Bulatnikovskaya & $-0.14^{*}$ & $-0.31^{* *}$ & -0.04 & 0.00 & $-0.40^{* *}$ & $-0.31^{* *}$ & -0.10 & $0.28^{* *}$
\end{tabular}

* correlation was significant at $p<0.05$

** correlation was significant at $p<0.01$

Table 5

RELATION OF AIR TEMPERATURE DURING 30 DAYS BEFORE FLOWERING TO FRUIT SET OF SOUR CHERRY CULTIVARS DURING 2009-2016

\begin{tabular}{l|cccc}
\hline \multirow{2}{*}{ Cultivar } & \multicolumn{4}{c}{ Kendall's tau b correlation coefficient of temperature $\left({ }^{\circ} \mathrm{C}\right)$ in 30 days long period before flowering with fruit set } \\
\cline { 2 - 5 } & minimum air temperature & average air temperature & maximum air temperature & average diurnal amplitude \\
\hline Latvijas Zemais & -0.03 & 0.01 & 0.07 & $0.17^{* *}$ \\
'Zentenes' & -0.09 & $-0.13^{*}$ & 0.09 & 0.09 \\
Orlica & $0.13^{*}$ & -0.04 & $-0.13^{*}$ & $0.17^{*}$ \\
Bulatnikovskaya & -0.03 & $-0.34^{* *}$ & -0.03 & -0.09
\end{tabular}

* correlation was significant at $p<0.05$

** correlation was significant at $p<0.01$ 
Fruit set of 'Bulatnikovskaya' was negatively affected by increasing number of days with precipitation, with a medium strong negative correlation $(p<0.01)$. Negative correlation between average air temperature before flowering and minimal air temperature during flowering with FS was observed. Longer duration of flowering had positive influence on FS $(p<0.01)$. Fruit set in the years with dominating southerly wind during flowering was significantly higher than in years with south-westerly wind $(25.5$ and $14.0 \%$, respectively) $(p<0.01)$.

No significant correlations were found between maximal air temperature or wind speed with FS.

'Orlica'. The average fruit set was $10.3 \%$, not significantly differing from that of 'Latvijas Zemais'. Unlike other cultivars, fruit set of 'Orlica' responded negatively to increase of maximum temperatures, but positively to increased wind speed $(p<0.01)$. There was a tendency of higher fruit set in years with dominating southerly wind during flowering comparing to years with various wind direction (14.3 and $7.4 \%$, respectively). No response of FS to minimum air temperature, number of days with precipitation, and duration of flowering time was detected. Effect of air temperature indices before flowering on fruit set was inconsistent.

\section{DISCUSSION}

A negative effect of increasing air average temperature (range from 7.7 to $17.5^{\circ} \mathrm{C}$ ) on fruit set during flowering was pronounced for all cultivars in our study. This indicated the ability of the investigated sour cherry cultivars to set fruits in rather cool weather conditions, but the amount of data was not large enough to identify threshold temperatures. However, the range of average temperatures during flowering, which have been reported as optimal in other studies, did not much differ from our conditions. In Poland, the average temperature of 14 and $16{ }^{\circ} \mathrm{C}$ during flowering was characterised as favourable for sour cherry fruit set in the field (Szpadzik et al., 2014), while temperatures from 9.96 to $16.63 \mathrm{C}$ were optimal for growth of pollen tube in style and ovary for several sweet cherry cultivars in laboratory conditions (Lech et al., 2012). Higher or lower temperature delayed the growth. In Serbia, temperature above $15{ }^{\circ} \mathrm{C}$ was necessary for pollen tube growth and penetration in the ovary locule for several sour cherry cultivars in laboratory conditions; however, the same cultivars set fruits at average temperature $11.2{ }^{\circ} \mathrm{C}$ in field conditions (Cerovič et al., 1997).

Increasing air relative humidity also showed pronounced negative effect on fruit set of all cultivars in our study. This might be explained disorder of pollen distribution by lower pollen release (Lech et al., 2012) and less airborne pollen (Hansted et al, 2012). There might be delayed pollen tube growth in conditions when humidity exceeds the optimum level (Lech et al., 2012). As there was close correlation of $\mathrm{RH}$ to average air temperature, negative effect on fruit set most probably was a result of both factors.
The cultivar 'Latvijas Zemais' showed increased fruit set in years with lower minimal temperature (range 0.8 to $-1.1{ }^{\circ} \mathrm{C}$ ) and with larger diurnal amplitude of temperature before flowering and during flowering. These results confirm the positive relationship of temperature with flowering (Nyéki et al., 2014). Temperature amplitude during 30 days before flowering negatively correlated with duration of flowering also in our study (Kendall's tau b coefficient $=$ $-0.72, p<0.01)$. There is still a question whether temperature drops during nights can delay ovule senescence and compensate the positive effect of high temperatures during the daytime.

Less pronounced was the effect of maximal air temperatures during flowering - a significant negative effect was detected only for 'Orlica'. In several studies, temperatures of 20 and $25{ }^{\circ} \mathrm{C}$ were related with comparatively fast senescence of sour cherry ovule (Postweiler et al., 1990; Cerovič and Ružič, 2010). In our study, maximal air temperature exceeded $25-28{ }^{\circ} \mathrm{C}$ in several years, and thus its negative effect on fruit set of 'Orlica' corresponds to results of the previously mentioned studies.

A positive effect of increasing wind speed on fruit set was detected also only for 'Orlica'. Taking into account its more pronounced sensitivity to maximal temperatures, a cooling effect of wind might be involved. On the other hand, wind may facilitate pollen distribution. Differences of FS response to wind between sour cherry cultivars might be explained by pollen morphology. Distinct and characteristic morphological traits of pollen were found for several genotypes of sour cherries (Nikolič and Milatovič, 2013) and of sweet cherries (Radičevič et al., 2013). Possibly, pollen of some genotypes are more readily distributed by wind. On the contrary, high wind speed is unfavourable for honeybee activity. The study of A. Stalažs in our trial showed that honeybees visited sour cherry flowers generally in low numbers; nevertheless, other species of pollen carrying insects were observed (Stalažs and Dreimanis, 2016).

Dominating southerly winds affected fruit set of cultivars 'Bulatnikovskaya' and 'Orlica' positively during flowering. Wind direction significantly affected localisation of insects within canopy, as they mostly visited the most protected side of trees (Stalažs and Dreimanis, 2016). On the northern side of trees temperature conditions might be more favourable for fertilisation. Higher fruit set in the northern part of trees was found for sour cherry cultivars 'Kántorjánosi' and 'Petri' in Hungary (Davarynejad et al., 2014).

Longer duration of flowering and less days with precipitation resulted in increased fruit set of 'Bulatnikovskaya'. This cultivar has abundant flowering and potential to set more fruits (Feldmane, 2010). Obviously, this potential was realised at a higher level if there was a longer time suitable for pollination.

Studies in Hungary showed the possibility and necessity to grow sour cherry cultivars that set big amount of fruits: 20 to $30 \%$ of flowers should set fruits (Lech, 1984; Nyeki et 
al., 1997). Fruit set could reach $50 \%$ for self-fertile cultivars (Davarynejad et al., 2014). In general, sour cherry fruit set was not as high in our study, but was adequate for the current cultivars (except 'Zentenes') and climatic conditions -a relatively short vegetation and long dormant period. The trees of cultivars 'Bulatnikovskaya' and 'Orlica' with highest fruit set sometimes showed signs of overproduction - small and low quality fruits and decreased growth of annual shoots. Productivity per ha of the current cultivars could be increased by closer planting distances between trees and more intensive pruning and growing technologies.

\section{ACKNOWLEDGEMENTS}

The research was supported by ESF project "Support for doctoral studies in LUA" and ESF project "Creation of a researcher group to investigate the possibilities of stone fruit trees propagation, quality improvement of generative processes and fruit usage".

\section{REFERENCES}

Cerovič. R., Micič, N., Šuric, G., Jevtič, S. (1997). Modelling pollen tube growth and ovule viability in sour cherry. Acta Hort., 468, 621-628.

Cerovič, R., Ružič, D. (1992). Pollen tube growth in sour cherry (Prunus cerasus L.) at different temperatures. J. Hortic. Sci., 67 (3), 333-340.

Cerovič, R., Ružič, D. (2010). Senescence of ovules at different temperatures and their effect on the behaviour of pollen tubes in sour cherry. Agricult. Water Manag., 98 (1), 12-18.

Davarynejad, G. H., Szabo, Z., Persley, Sz., Szabo T., Nyéki J. (2014). The fruit set capability of some sour cherry cultivars. Acta Hortic., 1020, $181-183$.

Feldmane, D. (2010) Precocity of sour cherry cultivars influenced by using woodchip mulch and drip irrigation. In: $16^{\text {th }}$ Annual International Scientific Conference "Research for Rural Development 2010", 19-21 May, Jelgava, pp. 48-55.

Hansted L., Grout, B. W. W., Eilenberg, J., Dencker, I. B., ToldamAndersen, T. B. (2012). The importance of bee pollination of the sour cherry (Prunus cerasus) cultivar 'Stevnsbaer' in Denmark. J. Pollin. Biol., 10 (6), 124-129.

Hedhly, A., Hormaza, J. I., Herrero, M. (2003). The effect of temperature on stigmatic receptivity in sweet cherry (Prunus avium L.). Plant Cell Environ., 26 (10), 1673-1680.
Lācis, G., Kota, I. (2013). SSR marker-based fingerprinting for sour cherry (Prunus cerasus) genetic resources identification and management. Acta Hort., 976, 251-256.

Lācis, G., Rashal, I., Trajkovski, V. (2011). Implemention of a limited set of SSR markers for screening of genetic variability in Latvian and Swedish sour cherry (Prunus cerasus L.) genetic resources collections. Proc. Latvian Acad. Sci., Section B, 65 (1/2), 21-28.

Lech, W., Małodobry, M., Dziedzic, E., Bieniasz, M., Doniec, S. (2012). Analysis of flowering of several sweet cherry cultivars in the climatic conditions of Southern Poland. Acta Hort., 932, 143-148.

Nikolič, D., Milatovič, D. (2013). Scanning electron microscopy study of pollen morphology of some sour cherry cultivars. In: VII International Cherry Symposium, 23-27 June 2013, Plasencia. Abstract book, p. 137.

Nyéki, J., Papp, N., Lakatos, L., Soltész, M., Szabo, Z., Hilsendegen, P, Balmer, M., Hegedus, A., Halisz, J., Szabó, T. (2014). Bloom phenology and fertility of sour cherry cultivars of Hungarian origin at two different growing sites. Acta Hort., 1020, 197-201.

Nyeki, J., Szabo, Z., Andrasfalvy, A. (1997). Morphological and phenological properties of sour cherry varieties grown in Hungary and their inter-incompatibility relations. Acta Hort., 468, 595-602.

Popovska, M., Angelova, E., Popovski, B. (2005). Microsporogenesis of sour cherries in Skopje region. Acta Hort., 667, 111-116.

Postweiler, K., Stösser, R., Anvari, S.F. (1990). The effect of different temperatures on the viability of ovules in cherries. Sci Hort, 43 (1-2), 103-108.

Radičevič, S., Cerovič, R., Nikolič, D., Šorševič, M. (2013). In vitro pollen germination and pollen grain morphology in some sweet cherry (Prunus avium L.) cultivars. Romanian Biotechnological Letters, 18 (3), 8341-8349.

Rodrigo, J., Herrero M. (2002). Effects of pre-blossom temperatures on flower development and fruit set in apricot. Sci Hort., 92 (2), 125-135.

Schuster, M., Wolfram, B. (2004). Results of sour cherry breeding in Dresden-Pillnitz. Acta Hort., 663, 911-914.

Spzadzik, E., Jadczuk-Tobjasz, E., Łotocka, B. (2014). Pollination, fertilization, autogamy degree and fruit set of some sour cherry cultivars in growing conditions of Poland. Acta Hort., 1020, 257-263.

Stalažs, A., Dreimanis J. (2016). Composition of anthophilous insects in Prunus cerasus and Prunus domestica (Rosaceae) orchards in Latvia: Preliminary notes on insect diversity. Zool. Ecol., 26 (2), 118-126.

Vicens, N., Bosch, J. (2000). Weather-dependent pollinator activity in an apple orchard, with special reference to Osmia cornuta and Apis mellifera (Hymenoptera: Megachilidae and Apidae). Environ. Entomol., 29 (3), 413-420

Zhang, L., Ampatzidis, Y., Whiting, M. D. (2015). Sweet cherry floral organ size varies with genotype and temperature. Sci. Hort., 182, 156-164.

\section{AUGḶU AIZMEŠANĀS VAIRĀKĀM SKĀBO ĶIRŠU ŠĶIRNĒM LATVIJĀ: ZIEDĒŠANAS LAIKA APSTĀKḶU IETEKME}

Pētījuma mērḳis bija novērtēt putekšṇu kvalitāti (dzīvotspēju un dīgtspēju) un laika apstākḷu pirms ziedēšanas un ziedēšanas laikā ietekmi uz aug̣̣u aizmešanos vairākām Latvijā audzētām skābo ķiršu šḳirnēm — 'Latvijas Zemais', 'Zentenes', 'Bulatņikovskaja' un 'Orḷica'. Pētījumu veica Dārzkopības institūtā, Dobelē, no 2009. līdz 2016. gadam. Škirnēm 'Latvijas Zemais' un 'Bulatnikovskaja' putekšnu dzīvotspēja un dīgtspēja bija pietiekami augsta. Zemāka aug̣̣u aizmešanās pakāpe tika konstatēta visām škirnēm, vidējām gaisa temperatūrām ziedēšanas laikā palielinoties no 7,7 līdz $17,5^{\circ} \mathrm{C}$ un relatīvajam gaisa mitrumam palielinoties no 51,4 līdz 88,5\%. Diennakts temperatūru svārstību ietekme pirms ziedēšanas un tās laikā, kā arī vēja un lietaino dienu skaita ietekme ziedēšanas laikā dažādām skābo kiršu škirnēm bija atškirīga. 